\title{
Examining the Entrepreneurship Sprit Condition among the Students of West Universities of Iran
}

\author{
Hossein Mehdi Zadeh ${ }^{1}$, Seidmehdi Veiseh ${ }^{2}$, Farideh Kamari ${ }^{3}$ \& Hamideh Shekari ${ }^{4}$ \\ ${ }^{1}$ Scientific board member and assistant professor of Ilam University, Iran \\ ${ }^{2}$ Department of Humanities, Ilam University and PHD student Payame Noor university, Tehran, Iran \\ ${ }^{3}$ Instractor of Ilam education organization and M.A in educational technology, Iran \\ ${ }^{4}$ Department of Management, Payame Noor University, Taft, Yazd, Iran \\ Correspondence: Seidmehdi Veiseh, Department of Humanities, Ilam University and PHD student Payame Noor \\ university, Tehran, Iran. Tel: 98-918-841-2908. E-mail: amir7912000@yahoo.com
}

\author{
Received: March 1, $2012 \quad$ Accepted: April 18, $2012 \quad$ Online Published: July 20, 2012 \\ doi:10.5539/ibr.v5n8p208 URL: http://dx.doi.org/10.5539/ibr.v5n8p208
}

\begin{abstract}
This survey was aimed to examine the job-making morale condition among the students of west universities of Iran. The population was composed of 445 students of universities such as medical schools, Azad universities, State universities and open universities (from Ilam, Kermanshah, Hamedan, Lorestan and Kurdistan). The samples were randomly selected. The gathered data was analyzed by use of SPSS software. Due to the results, the degree of job-making morale and its elements was high and the degree of functionality was low. There was also a meaningful difference between the job-making morale of males and job-making morale of females. Finally, there was a meaningful difference between the job-making morale of various groups of students based on the kind of available universities.
\end{abstract}

Keywords: entrepreneurial spirit, components of the entrepreneurial spirit, University of the West

\section{Introduction}

At the end of 20 century, business of the world changed. Today, some issues such as employment and unemployment are seriously mentioned by the researchers (Tajabadi, 2008). To solve this problem, politicians encounter some difficulties. Therefore, this is to say that decline or stability of some of governments is based on their problem solving (Salehi et al., 2006). Researches show that about 270 graduates are annually employed (Azizi \& Hosseini, 2006). Regarding the evidences and the increase of unemployment rate, it is hypothesized that entrepreneurship is of great importance. Evidences related to the developed (developing) countries show that the graduates can be prepared through entrepreneurship training and self-employment (Tag abadi, 2008). Entrepreneurship causes technical changes and economic growth of the societies. It also changes the new knowledge to the modern services (Shan et al., 2003). Kuratko and Hodgetts (2007) concluded that entrepreneurship is referred to a dynamic process composed of desire, change, transition and creativity. Luber (1998) argues that entrepreneurs are those who change the low productive recourses to the highly productive ones (Jamshidi Far et al., 2010).

Researches show that the entrepreneurship spirit can be improved by training (Razavi \& Nematolahi, 2005). Meanwhile, human recourse is one of the main elements relative to entrepreneurship. Human resource training can affect the improvement of entrepreneurship (Kuratko, 2003). The related problems can be solved by training entrepreneurship spirit and creating needed fields in order to develop the entrepreneurship activity of the graduates (Vahedi, 2010). Therefore, under the influence of the society's needs and conditions, the responsibilities of the universities change too (Elahi, 2009). High educations cause the entrepreneurship demand to improve through promoting knowledge. Basic and theoretical researches of the universities can improve the situation. New opportunities can be achieved through new ideas or techniques in order to present entrepreneurship processes (Shah Husseini, 2006).

Regarding the importance of the issue, some researches are presented as the following: 
Based on the results of their research, Shekar Shekan et al. (2002) concluded that there is a direct relationship between motivation of progress, creativity, self respect and entrepreneurship spirit of the students of Iran's Chamran University.

Another survey (HezarJaribi, 2003) revealed that there is a direct relationship between personal training, motivation of progress, risk- taking, autonomy, creativity and entrepreneurship.

Tajabadi (2008) concluded that there is no difference between men and women from their personal characteristics perspective. These characteristics include internal control center, autonomy, risk-taking, creativity and self respect.

In his survey about the performance of training programs, Salehi (2007) concluded that there is no difference between gender and entrepreneurship spirit of the students of Mazandaran's Universities.

Ali Beige et al. ( 2008) state that some of personal characteristics such as internal control center and risk-taking affect directly on the entrepreneurship spirit of the students. And concluded that the students have a better entrepreneurship spirit under the influence of autonomy, risk-taking, internal control center, motivation of progress and creativity. In this regard, there is no difference between males and females.

As illustrated in the figure below, 9 characteristics are regarded as the elements of entrepreneurship spirit.

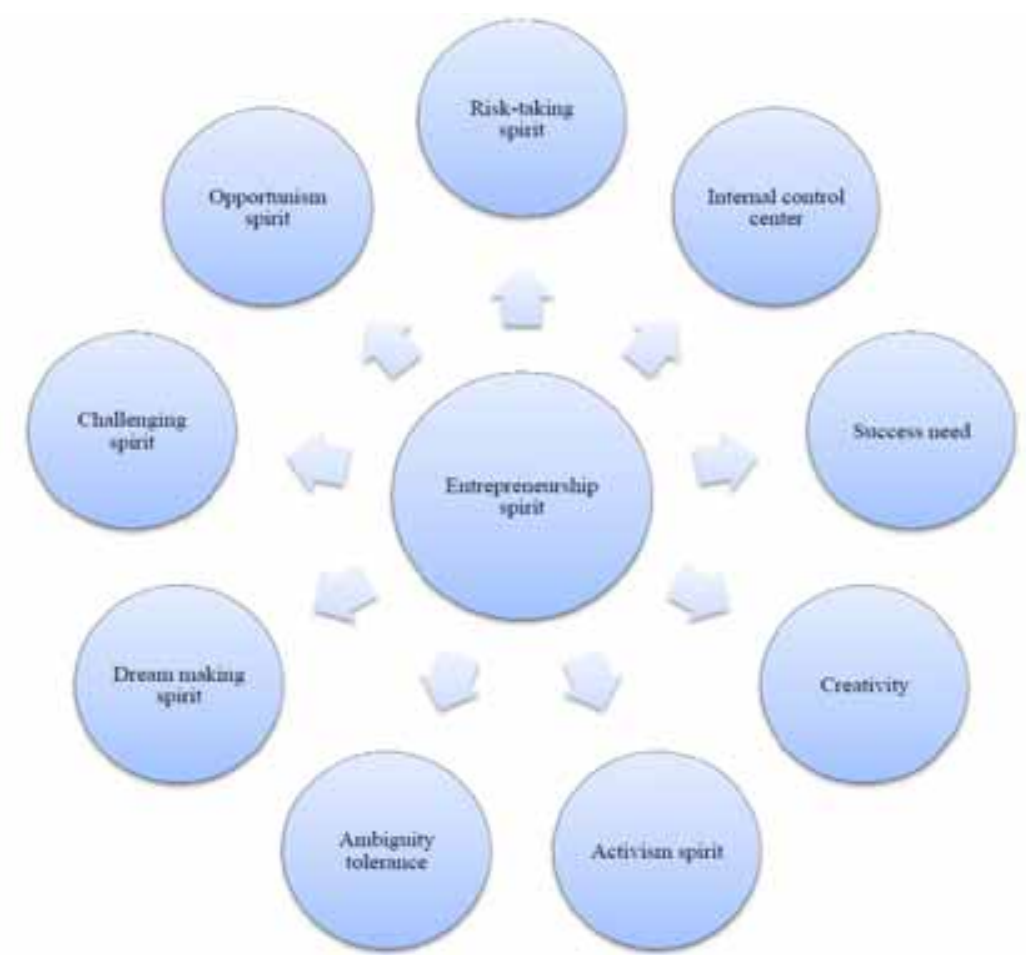

Figure 1. Conceptual model of elements entrepreneurship spirit

This survey explores the total condition of entrepreneurship spirit of the students of Iran's western universities. In this regard, the survey is aimed to investigate the followings:

1- the degree of difference between the males and females' entrepreneurship spirit

2- the degree of difference between the averages of students' entrepreneurship spirit based on the kind of their educational place (the students of public universities, open universities, azad universities and medical schools)

\section{Research Method}

From its methodological perspective, this survey is descriptive. Population includes all students of public, azad and open universities and medical schools of Ilam, Hamadan, Lorestan and Kurdistan. The students are studying at the second semester of 2009 from whom 445 ones were randomly selected. In this survey, entrepreneurship spirit includes 9 elements (risk-taking, internal control center, success need, creativity, activism spirit, tolerance ambiguity, dream making, challenging spirit and opportunism spirit. 8 out of 9 elements were measured by use of standard questionnaire of Naeij et al. (2007). This questionnaire included 95 multiple choice questions. In 
order to measure the level of opportunism spirit, a questionnaire designed by Tajabadi et al. (2008) was used. The questionnaire included 18 multiple - choice questions. Therefore, opportunism was regarded as the ninth variable evaluated by a special scope (strongly low $=1$, highly strong $=4$ ). In order to analyze data, the descriptive and the analytic method were used. The descriptive method included average and criterion evaluation, and the analytic method included t-test, variance analytic test and tailed test. The lowest meaningful difference (LSD) was also used.

\section{Research Findings}

Respondents included $63.8 \%$ female and $36.2 \%$ male students. 34.6\%, $22.9 \%$, $21.6 \%$ and $20.9 \%$ of them were from public universities, medical schools, Azad universities and open universities, respectively. $73 \%$ of the respondents were B.A students, 11.9\% were M.A students, 9.2\% were PHD and 5.9 were associated of arts students.

As shown in table 1 entrepreneurship spirit of the respondents is extremely high. Although the levels of riskmaking $(\mathrm{A}=2.79)$, creativity $(\mathrm{A}=2.59)$ and dream making $(\mathrm{A}=2.99)$, the level of internal control center (Average $=3.20)$, performance $(\mathrm{a}=3.39)$ and success $(\mathrm{A}=3.17)$ are high.

Table 1. Total condition of entrepreneurship of the students

\begin{tabular}{llllll}
\hline \multirow{2}{*}{ Elements } & Average & Criterion deviation & \multicolumn{2}{c}{ Reliability (95\%) } \\
\cline { 5 - 5 } & & & Min & Max \\
\hline 1 & Activism spirit & $3 / 39$ & $0 / 024$ & $3 / 34$ & $3 / 44$ \\
2 & Internal control center & $3 / 20$ & $0 / 023$ & $3 / 15$ & $3 / 24$ \\
3 & Success need & $3 / / 17$ & $0 / 019$ & $3 / 13$ & $3 / 21$ \\
4 & Opportunism spirit & $3 / 09$ & $0 / 022$ & $3 / 05$ & $3 / 13$ \\
5 & Entrepreneurship spirit & $3 / 05$ & $0 / 014$ & $3 / 02$ & $3 / 08$ \\
6 & Ambiguity tolerance & $3 / 08$ & $0 / 024$ & $3 / 03$ & $3 / 13$ \\
7 & Dream making spirit & $2 / 99$ & $0 / 026$ & $2 / 93$ & $3 / 04$ \\
8 & Challenging spirit & $3 / 05$ & $0 / 026$ & $3 / 00$ & $3 / 10$ \\
9 & Creativity & $2 / 94$ & $0 / 022$ & $2 / 91$ & $3 / 00$ \\
10 & Risk- taking spirit & $2 / 79$ & $0 / 023$ & $2 / 74$ & $2 / 83$ \\
\hline
\end{tabular}

In order to test hypotheses, t-test was used. As seen in table 2, there is a meaningful difference between the success of females and males $(t=2.1717$, sig $=0.007)$. The degree of males success requirement $(\mathrm{A}=3.10$, criterion deviation $=34 \%)$ is more than females $(\mathrm{A}=3.21$, criterion deviation $=24 \%)$. Also, there is a meaningful difference between the performance spirit $(t=4.484$, sig $=0.000)$ of males and females. The degree of activism spirit of females is more than the males.

Table 2. The t-test used for comparing the entrepreneurship of the students

\begin{tabular}{|c|c|c|c|c|c|c|}
\hline Elements & Gender & Average & Criterion deviation & $\mathrm{t}$ & sig & Results \\
\hline \multirow[t]{2}{*}{ Risk- taking spirit } & $\mathrm{F}$ & $2 / 77$ & $28 \%$ & $-0 / 722$ & $0 / 471$ & $\mathrm{~F}=\mathrm{M}$ \\
\hline & M & $2 / 80$ & $39 \%$ & & & \\
\hline \multirow[t]{2}{*}{ Internal control center } & $\mathrm{F}$ & $3 / 22$ & $29 \%$ & $1 / 508$ & $0 / 132$ & $\mathrm{~F}=\mathrm{M}$ \\
\hline & M & $3 / 15$ & $39 \%$ & & & \\
\hline \multirow[t]{2}{*}{ Success need } & $\mathrm{F}$ & $3 / 21$ & $24 \%$ & $2 / 717$ & $0 / 007$ & $\mathrm{~F}<\mathrm{M}$ \\
\hline & M & $3 / 10$ & $34 \%$ & & & \\
\hline \multirow[t]{2}{*}{ Creativity } & $\mathrm{F}$ & $2 / 96$ & $28 \%$ & $0 / 563$ & $0 / 574$ & $\mathrm{~F}=\mathrm{M}$ \\
\hline & M & $2 / 94$ & $36 \%$ & & & \\
\hline \multirow[t]{2}{*}{ Activism spirit } & $\mathrm{F}$ & $3 / 47$ & $28 \%$ & $4 / 484$ & $0 / 000$ & $\mathrm{~F}<\mathrm{M}$ \\
\hline & M & $3 / 25$ & $44 \%$ & & & \\
\hline \multirow[t]{2}{*}{ Ambiguity tolerance } & $\mathrm{F}$ & $3 / 07$ & $30 \%$ & $-0 / 271$ & $0 / 787$ & $\mathrm{~F}=\mathrm{M}$ \\
\hline & M & $3 / 09$ & $43 \%$ & & & \\
\hline \multirow[t]{2}{*}{ Dream making spirit } & $\mathrm{F}$ & $2 / 98$ & $31 \%$ & $-0 / 343$ & $0 / 732$ & $\mathrm{~F}=\mathrm{M}$ \\
\hline & M & $3 / 00$ & $47 \%$ & & & \\
\hline \multirow[t]{2}{*}{ Challenging spirit } & $\mathrm{F}$ & $3 / 06$ & $30 \%$ & $0 / 529$ & $0 / 597$ & $\mathrm{~F}=\mathrm{M}$ \\
\hline & M & $3 / 03$ & $49 \%$ & & & \\
\hline \multirow[t]{2}{*}{ Opportunism spirit } & $\mathrm{F}$ & $3 / 11$ & $25 \%$ & $1 / 065$ & $0 / 288$ & $\mathrm{~F}=\mathrm{M}$ \\
\hline & M & $3 / 06$ & $41 \%$ & & & \\
\hline \multirow[t]{2}{*}{ Entrepreneurship spirit } & $\mathrm{F}$ & $3 / 06$ & $17 \%$ & $1 / 519$ & $0 / 129$ & $\mathrm{~F}=\mathrm{M}$ \\
\hline & $\mathrm{M}$ & $3 / 02$ & $25 \%$ & & & \\
\hline
\end{tabular}


Based on the results, there is no difference between the entrepreneurship spirit (sig $=.29)$ and the elements such as risk - taking (sig $=.471$ ), ambiguity tolerance (sig $=.787$ ), dreaminess (sig $=.732$ ), challenging spirit (sig $=.597)$ and opportunism spirit (sig $=.288)$.

The variance test was used in order to examine the difference between entrepreneurship spirit and its elements. As illustrated in table 3, there is a significant difference between risk - taking spirit (sig $=.012, \mathrm{~F}=3.707$ ), internal control center ( $\operatorname{sig}=13 \%, \mathrm{~F}=3.648$ ), success requirement $(\mathrm{F}=2.622$, sig $=50 \%$ ), and activism spirit $(\mathrm{F}$ $=6.064$, sig $=0.000$ ) relative to the students. Moreover, the LSD test was used in order to investigate the significant difference between the elements of each group.

Table 3. The variance analysis test and the LSD test related to the comparison of the degree of students entrepreneurship spirit and its elements

\begin{tabular}{|c|c|c|c|c|c|c|}
\hline Elements & University & Average & Criterion deviation & $\mathrm{F}$ & Sig & result \\
\hline \multirow[t]{5}{*}{ Risk- taking spirit } & Medical & $2 / 76$ & $\% 47$ & \multirow[t]{5}{*}{$3 / 707$} & \multirow{5}{*}{$0 / 012$} & \multirow{5}{*}{$\begin{array}{l}\text { Medial schools }<\text { public, } \\
\text { azad, open universities }\end{array}$} \\
\hline & school & $2 / 82$ & \%39 & & & \\
\hline & Public U & $2 / 73$ & $\% 44$ & & & \\
\hline & Open U & $2 / 88$ & $\% 52$ & & & \\
\hline & Azad U & & & & & \\
\hline \multirow[t]{5}{*}{ Internal control center } & Medical & $3 / 30$ & $\% 41$ & \multirow[t]{5}{*}{$3 / 648$} & \multirow[t]{5}{*}{$0 / 013$} & \multirow{5}{*}{$\begin{array}{l}\text { Medial schools> public, } \\
\text { azad, open universities }\end{array}$} \\
\hline & school & $3 / 32$ & $\% 40$ & & & \\
\hline & Public U & $3 / 15$ & $\% 50$ & & & \\
\hline & Open U & $3 / 08$ & $\% 56$ & & & \\
\hline & Azad U & & & & & \\
\hline \multirow[t]{5}{*}{ Success need } & Medical & $3 / 21$ & $\% 38$ & \multirow[t]{5}{*}{$2 / 622$} & \multirow[t]{5}{*}{$0 / 050$} & \multirow{5}{*}{$\begin{array}{l}\text { Medial schools> public, } \\
\text { azad, open universities }\end{array}$} \\
\hline & school & $3 / 20$ & $\% 35$ & & & \\
\hline & Public U & $3 / 17$ & $\% 41$ & & & \\
\hline & Open U & $3 / 07$ & $\% 43$ & & & \\
\hline & Azad U & & & & & \\
\hline \multirow[t]{5}{*}{ Creativity } & Medical & $2 / 94$ & $\% 41$ & \multirow[t]{5}{*}{$0 / 942$} & \multirow[t]{5}{*}{$0 / 420$} & \multirow{5}{*}{$\begin{array}{l}\text { Medial schools=public, azad } \\
\text { open universities }\end{array}$} \\
\hline & school & $3 / 00$ & $\% 39$ & & & \\
\hline & Public U & $2 / 96$ & $\% 50$ & & & \\
\hline & Open U & $2 / 90$ & $\% 48$ & & & \\
\hline & Azad U & & & & & \\
\hline \multirow[t]{5}{*}{ Activism spirit } & Medical & $3 / 50$ & $\% 41$ & \multirow{5}{*}{ 6/064 } & \multirow[t]{5}{*}{$0 / 000$} & \multirow{5}{*}{$\begin{array}{l}\text { Medial schools= public, } \\
\text { azad, open universities }\end{array}$} \\
\hline & school & $3 / 40$ & $\% 42$ & & & \\
\hline & Public U & $3 / 45$ & $\% 54$ & & & \\
\hline & Open U & $3 / 21$ & $\% 57$ & & & \\
\hline & Azad U & & & & & \\
\hline Ambiguity tolerance & Medical & $3 / 10$ & $\% 44$ & $2 / 553$ & $0 / 055$ & Medial schools= public, \\
\hline & school & $3 / 14$ & $\% 44$ & & & azad, open universities \\
\hline & Public U & $2 / 95$ & $\% 59$ & & & \\
\hline & Open U & $3 / 07$ & $\% 50$ & & & \\
\hline & Azad U & & & & & \\
\hline Dream making spirit & Medical & $3 / 01$ & $\% 47$ & $0 / 100$ & $0 / 960$ & Medial schools=public, azad, \\
\hline & school & $2 / 98$ & $\% 47$ & & & open universities \\
\hline & Public & $2 / 97$ & $\% 61$ & & & \\
\hline & Open U & $2 / 98$ & $\% 58$ & & & \\
\hline & Azad U & & & & & \\
\hline Challenging spirit & Medical & $3 / 06$ & $\% 50$ & $0 / 651$ & $0 / 583$ & Medial schools $=$ public, \\
\hline & school & $3 / 09$ & $\% 45$ & & & azad, open universities \\
\hline & Public U & $3 / 01$ & $\% 59$ & & & \\
\hline & Open U & $3 / 01$ & $\% 62$ & & & \\
\hline & Azad U & & & & & \\
\hline Opportunism Spirit & Medical & $3 / 11$ & $\% 39$ & $0 / 983$ & $0 / 400$ & Medial schools= public, \\
\hline & school & $3 / 13$ & $\% 37$ & & & azad, open universities \\
\hline & Public U & $3 / 05$ & $\% 51$ & & & \\
\hline & Open U & $3 / 04$ & $\% 50$ & & & \\
\hline & Azad U & & & & & \\
\hline Entrepreneurship spirit & Medical & $3 / 06$ & $\% 25$ & $0 / 703$ & $0 / 166$ & Medial schools= public, \\
\hline & school & $3 / 09$ & $\% 26$ & & & azad, open universities \\
\hline & Public U & $3 / 02$ & $\% 30$ & & & \\
\hline & Open U & $3 / 01$ & \% 31 & & & \\
\hline & Azad U & & & & & \\
\hline
\end{tabular}


One of the results (table 3), the risk- taking spirit of the students of medical school (sig $=2.67, \mathrm{~F}=47 \%$ ) is less than the other groups.

Also, the internal control center of the students of medical schools ( $\mathrm{sig}=3.08, \mathrm{~F}=56 \%$ ) is more than the others. These students need more success compare to the other students. The activism spirit of the students of medical schools is more than the other students.

The results of variance analysis test show that there is no significant difference between the all students creativity (sig $=.420)$ of ambiguity tollerance $(\mathrm{sig}=55 \%)$, dream - making $(\mathrm{sig}=.960)$, challenging $(\mathrm{sig}=.583)$, activism spirit (sig $=.166)$.

\section{Conclusion}

According to the results, the entrepreneurship spirit of the students of Iran's western universities is highly desired. Also, the success need and the activism spirit of the girls is more than the boys (Rezaee \& Rahsepar, 2009). These results are not proportional to the results of the researches done by Rostami \& Salehi Omran (1386) and Ali beigi et al. (2008). During recent years, self employment of the women has improved. This is because entrepreneurship prepares a situation in which the women can reach their objectives. Results show that there is no direct difference between the entrepreneurship of various universities, but there is a direct difference between risk - taking spirit, internal control center, success need and activism spirit of the students based on their education place. Therefore, the students of medical schools have a weaker risk - taking spirit but they have a stronger control center and activism spirit in comparison with the other students. There is no evidence to show that the other researchers have the same results. Therefore, this comparison is mainly on the basis of educational field.

\section{References}

Alahi, F. (2009). Evaluation of the effectiveness of their online students in creating an entrepreneurial spirit. (Thesis MA). Islamic Azad University, Kermanshah.

Ali Beigi, A., Athari, Z., \& Barani, S. H. (2008). The entrepreneurial spirit of students - a case study of agricultural applications of Kermanshah, the National Seminar on Entrepreneurship Development in Agriculture. Applied Science Education, March 2008, Kermanshah, Iran.

Azizi, M., \& Sabaghian, G. (2009). Comparing the characteristics of male and female entrepreneurs. Encyclopedia of Entrepreneurship, 2, 65-73.

Hezar Jaribi, J. (2003). Review of entrepreneurial graduates in the humanities and social-cultural issues in Tehran. (PhD thesis). Faculty of Literature and Humanities Tehran University.

Jamshidi, F. M., Khorrami, L. A., \& Raheli. H. (2010). Examined factors affecting the entrepreneurial spirit of students of Tabriz Faculty of Agriculture. Agricultural Extension and Research, Third Year, No. 3. pp. 35-49.

Kordnaejj, A., Zali, M., Hooman, H., \& Shams, S. H. (2007). Instruments measuring personality traits entrepreneur. Tarbiat Modarres University, pp. 220-236.

Kuratko, D. F., \& Donaed, F. (2003). Entrepreneurship Education: Emerging Trends and Challenges for the 21st Sentry. Coleman White Paper Series, 2003.

Kuratko, D. F., \& Hodgetts, R. M. (2007). Entrepreneur, ship: Theory, process, Practice. Mason, OH: south-western college publishers.

Razavi, N. (2005). Concepts of entrepreneurship and Generalities (pp. 10-22). New York, No. 3677.

Rezaei, M. H., \& Rahsepar, T. (2009). Examine how the entrepreneurial characteristics of Islamic Azad University, Fars, Journal - a new approach for research in educational management, Second Year, No. IV, Summer 2009, pp. 62-45.

Salehi, O. A. (2007). Higher education and fostering entrepreneurial spirit in the University of Mazandaran. Proceedings of Conference on Entrepreneurship, Management Sciences, Iran, pp. 135-151.

Shan, S., Locke, E., \& Collin, C. (2003). Entrepreneurial motivation. Human resource management Review, 13, 257-279. http://dx.doi.org/10.1016/S1053-4822(03)00017-2

Shekarshekan, H., Bromandnassab, M., Najarian, B., \& Shahny Yelaghi, M. ( 2002). The relationship of simple and multiple creativity, self-esteem, achievement motivation and entrepreneurship at the University of 
Shahid Chamran, Shahid Chamran University of Science Education and Psychology, Volume III, ninth year, numbers 3 and 4, pp.1-24.

Tajabady, B. (2008). Entrepreneurship training and development methods and its application in agricultural higher education system. The National Conference on Entrepreneurship, Culture and Society, University Roodehen, pp. 87-104.

Vahedi, M., Moradnzhady, H., \& Sharifi, M. (2010). Examined ntrepreneurial characteristics, Islamic Azad University, Ilam, Iran. Journal of Agricultural and Development Economics Research, 2, 40-51. 